\title{
Incidence of chickpea pod borer and monitoring of pod borer moths by using pheromone traps
}

\author{
A.M. BHARADIYA, R.M. JAVIA* AND M.S. PITHIA \\ Pulses Research Station (J.A.U.), JUNAGADH (GUJARAT) INDIA \\ (Email : rmjavia@gmail.com)
}

\begin{abstract}
Present study was carried out on chickpea to find out the incidence of pod borer as well as monitoring of pod borer at Pulses Research Station, Junagadh Agricultural University, Junagadh (Gujarat) during Rabi seasons 2011-12, 2012-13 and 201314. The results revealed that larval population of Helicoverpa armigera was varied from 0.86 to $2.55 \mathrm{larvae} / \mathrm{mrl}$ at $30 \mathrm{DAS}$. More or less similar pattern was observed at 45 and 75 DAS, while larval population varied from 1.45 to 3.20 and 1.26 to 3.02 larvae/mrl, respectively. At $60 \mathrm{DAS}$ treatment $\mathrm{D}_{2} \mathrm{~V}_{1}$ noted lowest larval population $\left(0.58\right.$ larvae/mrl). The treatment $\mathrm{D}_{1} \mathrm{~V}_{3}$ recorded the lowest pod damage of 3.66, 3.95, 4.03 and 3.88 per cent in 2011-12, 2012-13, 2013-14 and pooled results, respectively. Seed yield was varied from 825 to $1612 \mathrm{~kg} / \mathrm{ha}$. The activity of male moths began from $50^{\text {th }}$ standard week of December to $9^{\text {th }}$ standard week of February / March. The peak period was observed from $1^{\text {st }}$ standard week to $4^{\text {th }}$ standard week of January.
\end{abstract}

Key Words : Chickpea, Gram pod borer, Helicoverpa armigera, Incidence, Monitoring

View Point Article : Bharadiya, A.M., Javia, R.M. and Pithia, M.S. (2017). Incidence of chickpea pod borer and monitoring of pod borer moths by using pheromone traps. Internat. J. agric. Sci., 13 (1) : 62-66, DOI:10.15740/HAS/IJAS/13.1/62-66.

Article History : Received : 16.10.2016; Revised : 11.11.2016; Accepted : 13.12.2016

* Author for correspondence: 